\title{
PGPR Characteristics of Rhizospheric Bacteria to Understand the Mechanisms of Faba Bean Growth ${ }^{\dagger}$
}

\author{
Rim Tinhinen Maougal ${ }^{1,2, *}$, Maya Kechid ${ }^{1,2}$, Chaima Ladjabi ${ }^{3}$ and Abdelhamid Djekoun 1 \\ 1 Laboratoire Génétique Biochimie et Biotechnologie Végétale, SNV Université frères Mentouri Constantine 1, \\ Constantine 25000, Algeria; maya.kechid@umc.edu.dz (M.K.); djak2591@gmail.com (A.D.) \\ 2 Institut de la Nutrition, de l'Alimentation et des Technologies Agro-alimentaires (INATAA), Département \\ de Biotechnologie alimentaire, Université Frères Mentouri, Constantine 1, Constantine25000, Algeria \\ 3 Départements d'écologie et biologie végétale, SNV Université frères Mentouri Constantine 1, \\ Constantine 25000, Algeria; ladjabichaima94@hotmail.com \\ * Correspondence: rym.maougal@umc.edu.dz \\ + Presented at the 1st International Electronic Conference on Microbiology, 2-30 November 2020; Available \\ online: https://ecm2020.sciforum.net/.
}

Published: 11 January 2021

\begin{abstract}
Rhizobacteria play an important role in maintaining soil balance. Among these bacteria, there are those taht have shown their ability to promote the growth of plants, known as Plant Growth Promoting Rhizobacteria (PGPR). In our work, we are interested in characterizing 110 bacterial strains isolated in the field in the region of Ben Badis (Constantine Algeria) from 5 varieties of faba bean. Phenotypic and biochemical characterization showed that most of the isolates are cream-colored, slightly raised, flat and opaque, Gram-, catalase+ and oxidase-, and Bacillus form. PCA analysis allowed us to select 40 isolates with a high degree of variability to continue our work. The results obtained have directed us towards different taxonomic groups (rhizobium, Pseudomonas, Bacillus etc.). The evaluation of the PGPR potential of bacteria (phytostimulation, biofertilization and biocontrol), showed that $100 \%$ of bacteria are able to produce auxin at different concentrations, with the highest concentration $(177.77 \mu \mathrm{g} / \mathrm{mL})$ for the isolate 6 , and that more than $50 \%$ of isolates are capable of producing nitrogen, ammonia and phytate mineralization. These PGPR traits have a direct effect on plant growth of five varieties of the faba bean and can be used to select the best performing bacteria for inoculation tests.
\end{abstract}

Keywords: growth promotion; faba bean; rhizosphere; PGPR traits

\section{Introduction}

The soil is an important reservoir for microorganisms, as it contains a complex and varied microflora that play essential roles for the telluric ecosystem and the multi-cellular organisms that live there. Among the higher soil organisms, plants benefit from the direct and/or indirect effects of microorganisms, in particular those of the rhizospheric flora [1].

PGPR bacteria (Plant Growth Promoting Rhizobacteria) are part of this type of microorganism because they do not establish a mutualistic symbiosis relationship, but promote the growth of plants with which they are associated [2]. The selection of an effective PGPR strain is linked to the characterization of its properties promoting plant growth such as: the solubilization of phosphate, the production of siderophores and phytohormones, the ability to fix nitrogen, and the biological control of diseased plants [3].

The objective of this work is to pre-identify bacteria previously isolated from the rhizosphere of faba bean, our plant model in this study, based on their morphological characters: macroscopic, microscopic, biochemical and physiological. 


\section{Methods}

Strains of bacteria were isolated from rhizosphere of faba bean, roots are washed and soil solution obtained was used for the isolation of non-symbiotic bacteria. Physiological and biochemical characteristics of the bacterial isolates were examined according to the methods described by the Bergey's manual [4]. Different assays and tests allowed to test the PGPR functions.

\section{Results and Discussion}

The phenotypic characterization of the 110 rhizobacteria showed that most isolates are Gram$(94.54 \%)$, catalase $+(87.5 \%)$, oxidase- $(65 \%)$, slightly raised $(27.27 \%)$, flat $(61.81 \%)$, and opaque $(50.9 \%)$, round in shape $(60 \%)$, and in different colors, Bacillus form $(60 \%)$.

The detection of pyoverdin pigment by observation of a yellow-green color shows that $55.45 \%$ of the bacteria exhibited a yellow-green fluorescence against $43.63 \%$ without fluorescence This fluorescence could be indicative of the affiliation of the bacteria to the species Pseudomonas fluorescent.

The factorial analysis of these tests allowed us to realize a point cloud gathering the isolates with a certain degree of similarity. We used the PCA to select the 40 isolates with a high degree of variability to continue our work.

The study of the Plant Growth Promoting Rhizobacteria (PGPR) effect of rhizobacteria showed that $100 \%$ of the isolates tested are able of producing auxin at $177.77 \mu \mathrm{g} / \mathrm{mL}$ concentration (Strain 6).

The solubilization efficiency of phosphates from our isolates measured on NBRIP medium [5]. showed that $50 \%$ of isolates were able to grow on a medium containing phytate as the sole source of phosphorus so they are able to degrade phytate.

The growth of bacteria on "Burk's N-free" medium depends on their ability to fix nitrogen our results showed that $72.5 \%$ of the isolates tested were able to fix nitrogen.

The appearance of the medium after incubation at $30{ }^{\circ} \mathrm{C}$ and addition of Nessler's reagent showed that $67.5 \%$ of the media appear yellowish or orange in color, which corresponds to ammonium-producing bacteria.

\section{Conclusions}

Through this present work and the experiments carried out, we have affirmed the presence of a relationship between the bacteria of the rhizosphere of the plant vicia faba in the region of Constantine (Algeria) thanks to their important agro-economic, environmental and ecological interests.

Better knowledge of the mechanisms of plant-microorganism interaction makes it possible to promote populations already present in the rhizosphere and which are beneficial for plants. Therefore, its isolates can be further studied and developed, in order to be used in agriculture and biotechnology.

\section{References}

1. Munees, A.; Mulugeta, K. Mechanisms and applications of plant growth promoting rhizobacteria: Current perspective. J. King Saud Univ. Sci. 2013, 26, 1-20.

2. [Kloepper, J.W.; Beauchamp, C.J. A review of issues related to measuring colonization of plant roots by bacteria. Can. Microbiol. 1992, 38, 1219-1232.

3. Cattelan, A.J.; Hartel, P.G.; Fuhrmann, J.J. Screening for plant growth-promoting rhizobacteria to promote early soybean growth. Soil Sci. Soc. Am. J. 1999, 63, 1670-1680.

4. Holt, J.G.; Krieg, N.R.; Sneath, P.H.A.; Stanley, J.T.; Williams, S.T. Bergey's Manual of Determinative Bacteriology, 9th ed.; Williams \& Wilkins, Co.: Baltimore, MD, USA, 1994. 
5. Kumar, A.; Devi, S.; Patil, S.; Payal, C.; Negi, S. Isolation, screening and characterization of bacteria from rhizospheric soils for different plant growth promotion (PGP) activities: An in vitro study. Recent Res. Sci. Technol. 2012, 4, 1-5.

Publisher's Note: MDPI stays neutral with regard to jurisdictional claims in published maps and institutional affiliations.

(C) 2021 by the authors. Licensee MDPI, Basel, Switzerland. This article is an open access article distributed under the terms and conditions of the Creative Commons Attribution (CC BY) license (http://creativecommons.org/licenses/by/4.0/). 